\title{
3,4-Secocycloartane Triterpenoids from the Cones of Pseudolarix amabilis
}

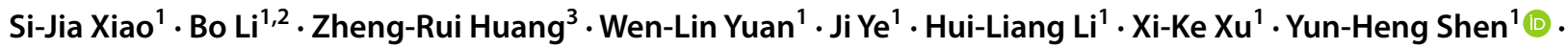 \\ Wei-Dong Zhang ${ }^{1,2}$
}

Received: 9 October 2020 / Accepted: 9 November 2020 / Published online: 3 January 2021

(c) The Author(s) 2021

\section{Abstract}

Four new 3,4-secocycloartane triterpenoids, pseudolactones A-D (1-4), were isolated from the ethanol extract of the cones of Pseudol arixamabilis. Their structures were established by extensive 1D- and 2D-NMR experiments. The cones of $P$. arixamabilis are enriched in the ring-expanded or cleaved cycloartane triterpenoids. This work provides new insight into cycloartane triterpenoids from the cones of $P$. arixamabilis.

\section{Graphic Abstract}
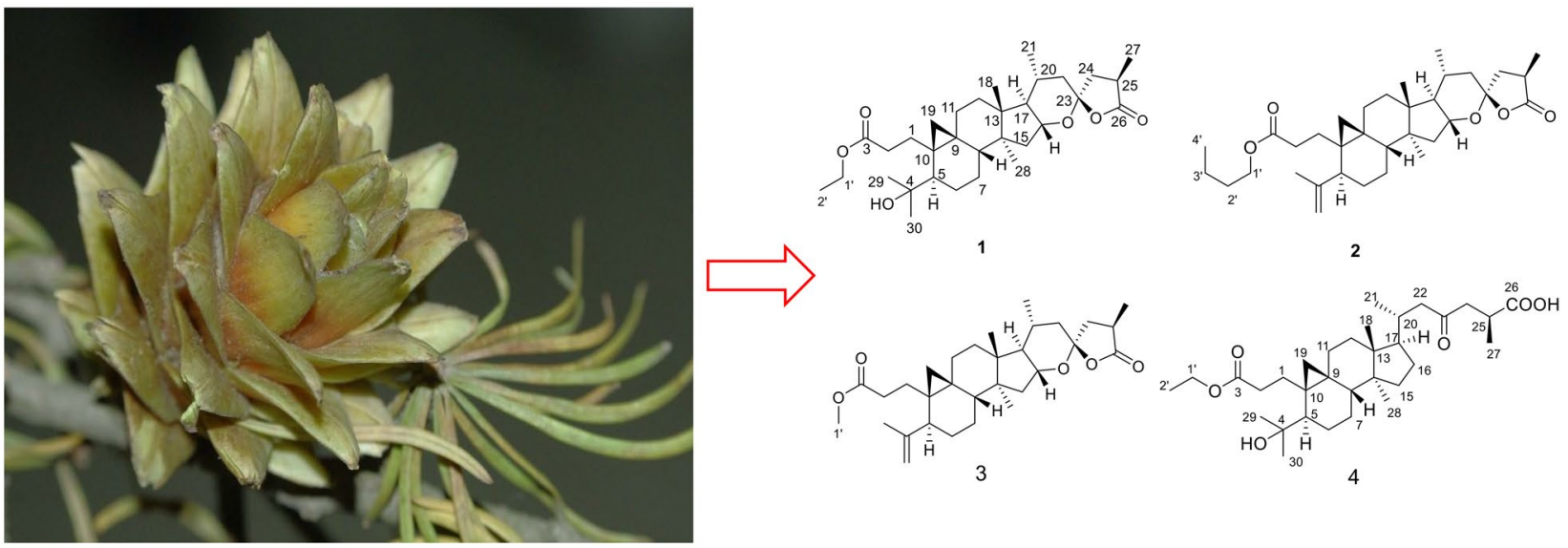

The cones of Pseudolarix amabilis

Keywords Pseudol arixamabilis $\cdot$ Triterpenoids $\cdot 3,4$-Secocycloartane $\cdot$ Pseudolactones A-D

This paper is dedicated to the memorial of Professor Jun Zhou.

Si-Jia Xiao and Bo Li contributed equally to this work.

Electronic supplementary material The online version of this article (https://doi.org/10.1007/s13659-020-00285-7) contains supplementary material, which is available to authorized users.

Extended author information available on the last page of the article

\section{Introduction}

Pseudolarix amabilis is a plant indigenous to the south-east of China [1]. The root and trunk barks of it, known as 'Tu Jin $\mathrm{Pi}^{\prime}$ ' in traditional Chinese medicine, have been used to treat skin diseases caused by fungal infection [2,3]. Previous phytochemical studies on the root barks and seeds of $P$. amabilis revealed a variety of bioactive compounds with novel structures, with the main chemical constituents being pseudolaric acid analogous and triterpenoids [4-9]. Some 
of them, such as psedolaric acids A and B [10], have shown potent antimicrobial and cytotoxic activities. Peudolarolide $\mathrm{B}$, a triterpene lactone, has shown potent cytotoxic activity [8]. Novel nortriterpenoid lactone, pseudolarenone [11], as well as triterpenoid-diterpenoid dimers [12], have also been reported from the cones of this plant. In this paper, we describe the isolation and structure elucidation of four new 3,4-secocycloartane triterpenoids from the cones of $P$. amabilis.

\section{Results and Discussion}

The dried cones of $P$. amabilis, collected in Jiujiang, Jiangxi province, P. R. China, were extracted with $80 \% \mathrm{EtOH}$ for three times at room temperature. The extract was separated by chromatography techniques to yield four new triterpenes, pseudolactones A-D (1-4) (Fig. 1). The structures of four new triterpenoids were determined by analysis of HRESIMS and NMR spectroscopic data.

Compound 1 corresponds to the molecular formula $\mathrm{C}_{32} \mathrm{H}_{50} \mathrm{O}_{6}$ as established by the hydrogen adduct ion peak at $m / 2531.3678[\mathrm{M}+\mathrm{H}]^{+}$(calcd. 531.3680 for $\mathrm{C}_{32} \mathrm{H}_{51} \mathrm{O}_{6}{ }^{+}$) in HR-ESI-MS spectrum, indicative of 8 degrees of unsaturation.

The ${ }^{1} \mathrm{H}$ NMR spectrum (Table 1) of $\mathbf{1}$ showed four tertiary $\left(\delta_{\mathrm{H}} 1.00(\mathrm{~s}), 1.17(\mathrm{~s}), 1.18(\mathrm{~s}), 1.08(\mathrm{~s})\right)$ and two secondary $\left(\delta_{\mathrm{H}} 0.86(\mathrm{~d}, J=6.4 \mathrm{~Hz}), 1.19\right.$ (overlap)) methyls. Moreover, an oxygenated proton signal was observed at $\delta_{\mathrm{H}} 4.05$. In ${ }^{13} \mathrm{C}$ NMR spectrum (Table 2), there existed 32 carbon resonances, which were sorted into seven methyls, eleven methylenes, six methines (including one oxygenated methane at $\delta_{\mathrm{C}} 77.4$ ), and eight quaternary carbons (including two ester carbonyls at $\delta_{\mathrm{C}} 174.6$ and 179.7 , an oxygenated quaternary carbon at $\delta_{\mathrm{C}} 76.1$, and a ketal carbon at $\left.\delta_{\mathrm{C}} 107.3\right)$, by DEPT NMR spectrum. The above evidences, combined with the characteristic methylene protons at $\delta_{\mathrm{H}} 0.51(\mathrm{~d}, J=4.4 \mathrm{~Hz})$ and $0.70(\mathrm{~d}, J=4.4 \mathrm{~Hz})$ as well as the carbon resonances at $\delta_{\mathrm{C}} 32.4(\mathrm{t}), 21.8(\mathrm{~s})$, and $27.6(\mathrm{~s})$, revealed a cyclopropyl motif. The diagnostic chemical shifts for two ester carbonyls at $\delta_{\mathrm{C}} 174.6(\mathrm{C}-3)$ and $179.7(\mathrm{C}-26)$, one oxygenated methine at $\delta_{\mathrm{C}} 77.4$, and the ketal carbon at $\delta_{\mathrm{C}} 107.3$, implied that compound 1 might be a 3,4-secocycloartane triterpenoid with a unique 16,23-epoxy-23,26-spirolactone side chain.

Comparison of the NMR spectroscopic data of compound 1 with those of known pseudolarolide C [8] indicated that they were structurally quite similar except that an additional ethoxy in compound $\mathbf{1}\left(\delta_{\mathrm{H}} 1.19(3 \mathrm{H}), 4.05\right.$ $\left.(2 \mathrm{H}) ; \delta_{\mathrm{C}} 14.1,60.2\right)$ replaced the methoxyl in pseudolarolide $\mathrm{C}$, which was confirmed by key ${ }^{1} \mathrm{H}-{ }^{1} \mathrm{H}$ COSY correlations (Fig. 2) of $\mathrm{H}_{2}-1^{\prime} / \mathrm{H}_{3}-2^{\prime}$ and $\mathrm{HMBC}$ correlation from $\mathrm{H}_{2}-1^{\prime}$ $\left(\delta_{\mathrm{H}} 4.05\right)$ to carboxylic carbon $\mathrm{C}-3\left(\delta_{\mathrm{C}} 174.6 \mathrm{ppm}\right)$. The structure of 1 was further evidenced by key ${ }^{1} \mathrm{H}-{ }^{1} \mathrm{H}$ COSY correlations of $\mathrm{H}_{2}-2 / \mathrm{H}_{2}-1, \mathrm{H}-5 / \mathrm{H}_{2}-6 / \mathrm{H}_{2}-7 / \mathrm{H}-8, \mathrm{H}_{2}-11 / \mathrm{H}_{2}-$ $12, \mathrm{H}_{2}-15 / \mathrm{H}-16 / \mathrm{H}-17 / \mathrm{H}-20\left(\mathrm{H}_{3}-21\right) / \mathrm{H}_{2}-22$ together with key HMBC correlations (Fig. 2) from $\mathrm{H}_{2}-2, \mathrm{H}_{2}-19, \mathrm{H}_{2}-6$ to C-10 $\left(\delta_{\mathrm{C}} 27.6\right)$, from $\mathrm{H}_{2}-11, \mathrm{H}-15$ to $\mathrm{C}-13\left(\delta_{\mathrm{C}} 43.5\right)$, from $\mathrm{H}_{2}-12, \mathrm{H}-16$ to $\mathrm{C}-14\left(\delta_{\mathrm{C}} 47.3\right)$, from $\mathrm{H}_{2}-22, \mathrm{H}-16, \mathrm{H}_{2}-24$ to $\mathrm{C}-23\left(\delta_{\mathrm{C}} 107.3\right)$, and $\mathrm{H}_{3}-27$ to $\mathrm{C}-26\left(\delta_{\mathrm{C}} 179.7\right)$. The relative configurations of 1 were elucidated to be identical with those of pseudolarolide $\mathrm{C}$ on the basis of the REOSY correlations (Fig. 2) of H-19 with $\mathrm{H}-8, \mathrm{H}-8$ with $\mathrm{CH}_{3}-18$, $\mathrm{CH}_{3}-18$ with $\mathrm{H}-16, \mathrm{H}-16$ with $\mathrm{H}-20, \mathrm{H}-17$ with $\mathrm{CH}_{3}-28$ and $\mathrm{CH}_{3}-21, \mathrm{H}-22$ with $\mathrm{H}-24$, and $\mathrm{H}-24$ with $\mathrm{CH}_{3}$-27. In cycloartane triterpenoids, the $\mathrm{C}-20$ position of the 17 -side chain is usually $R$-configuration. From the biogenetic point of view,
Fig. 1 Chemical structures of 1-4
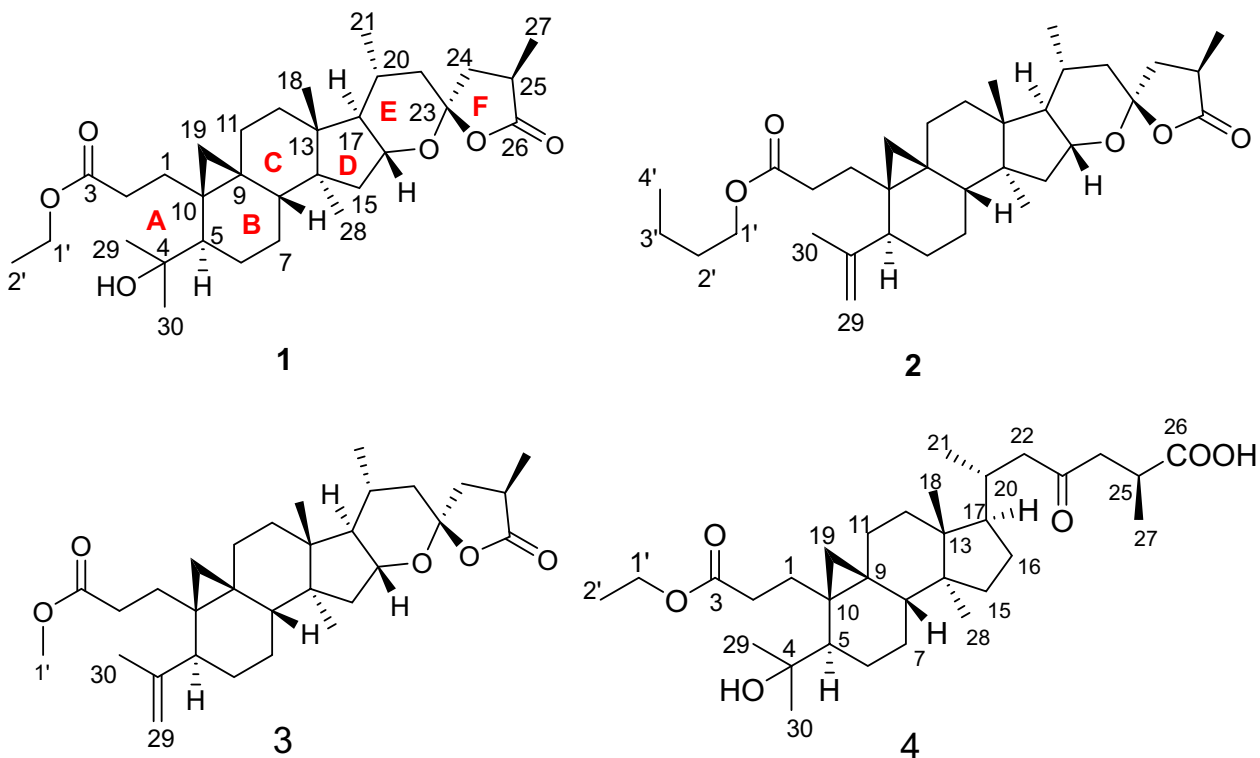
Table $1{ }^{1} \mathrm{H}$ NMR (400 MHz) spectroscopic data for compounds $\mathbf{1}-\mathbf{4}$ in $\mathrm{CDCl}_{3}(\mathrm{~J}$ in $\mathrm{Hz})$

\begin{tabular}{|c|c|c|c|c|}
\hline \multirow[t]{2}{*}{ No. } & \multicolumn{4}{|l|}{$\delta_{\mathrm{H}}(\delta$ in ppm, $J$ in $\mathrm{Hz})$} \\
\hline & 1 & 2 & 3 & 4 \\
\hline \multirow[t]{2}{*}{1} & $2.17 \mathrm{~m}$ & 1.35 overlap, & $1.34 \mathrm{~m}$ & 2.29 ddd $(4.0,9.2,15.6)$ \\
\hline & 2.59 ddd $(6.0,10.0,16.0)$ & $2.03 \mathrm{dd}(2.8,6.0,16 . .0)$ & $2.02 \mathrm{dd}(6.0,16.0)$ & $2.60 \mathrm{ddd}(5.6,10.0,15.6)$ \\
\hline \multirow[t]{2}{*}{2} & 1.31 overlap & $2.22 \mathrm{~m}$ & $2.21 \mathrm{~m}$ & $1.36 \mathrm{~m}$ \\
\hline & 2.64 ddd $(6.0,10.8,16.4)$ & 2.49 ddd $(6.0,12.0,15.6)$ & $2.48 \mathrm{ddd}(6.0,12.0,15.6)$ & $2.15 \mathrm{~m}$ \\
\hline \multicolumn{5}{|l|}{3} \\
\hline \multicolumn{5}{|l|}{4} \\
\hline 5 & $1.27 \mathrm{~m}$ & 2.41 overlap & 2.38 overlap & $1.85 \mathrm{~m}$ \\
\hline \multirow[t]{2}{*}{6} & $0.63 \mathrm{~m}$ & $1.08 \mathrm{~m}$ & 1.05 overlap & $0.69 \mathrm{~m}$ \\
\hline & $1.69 \mathrm{~m}$ & $1.51 \mathrm{~m}$ & $1.48 \mathrm{~m}$ & $1.73 \mathrm{~m}$ \\
\hline \multirow[t]{2}{*}{7} & $0.96 \mathrm{~m}$ & $1.10 \mathrm{~m}$ & 1.05 overlap & $1.23 \mathrm{~m}$ \\
\hline & $1.23 \mathrm{~m}$ & 1.26 overlap & $1.23 \mathrm{~m}$ & $1.28 \mathrm{~m}$ \\
\hline 8 & $1.82 \mathrm{~m}$ & $1.53 \mathrm{~m}$ & $1.50 \mathrm{~m}$ & $1.30 \mathrm{~m}$ \\
\hline \multicolumn{5}{|l|}{9} \\
\hline \multicolumn{5}{|l|}{10} \\
\hline \multirow[t]{2}{*}{11} & $2.10 \mathrm{~m}$ & $2.17 \mathrm{~m}$ & $2.13 \mathrm{~m}$ & $1.20 \mathrm{~m}$ \\
\hline & 1.20 overlap & 1.26 overlap & $1.26 \mathrm{~m}$ & $1.87 \mathrm{~m}$ \\
\hline \multirow[t]{2}{*}{12} & $1.40 \mathrm{~m}$ & $1.68 \mathrm{~m}$ & $1.57 \mathrm{~m}$ & 1.64 overlap \\
\hline & $1.14 \mathrm{~m}$ & 1.58 overlap & $1.66 \mathrm{~m}$ & 1.40 overlap \\
\hline \multicolumn{5}{|l|}{13} \\
\hline \multicolumn{5}{|l|}{14} \\
\hline \multirow[t]{2}{*}{15} & 1.21 overlap & 1.23 overlap & $1.20 \mathrm{~m}$ & $1.33 \mathrm{~m}$ \\
\hline & $1.72 \mathrm{~m}$ & $1.79 \mathrm{dd}(11.2,14.0)$ & $1.75 \mathrm{dd}(11.2,12.4)$ & 1.62 overlap \\
\hline \multirow[t]{2}{*}{16} & 4.05 overlap & $4.09 \operatorname{td}(5.6,11.2)$ & $4.06 \mathrm{~m}$ & 1.39 overlap \\
\hline & & & & 2.64 ddd $(4.0,8.8,15.6)$ \\
\hline 17 & $1.43 \mathrm{~m}$ & $1.47 \mathrm{~m}$ & $1.45 \mathrm{~m}$ & 1.63 overlap \\
\hline 18 & $1.00 \mathrm{~s}$ & $1.04 \mathrm{~s}$ & $1.01 \mathrm{~s}$ & $1.00 \mathrm{~s}$ \\
\hline \multirow[t]{2}{*}{19} & $0.51 \mathrm{~d}(4.4)$ & $0.42 \mathrm{~d}(4.8)$ & $0.39 \mathrm{~d}(4.8)$ & $0.57 \mathrm{~d}(4.4)$ \\
\hline & $0.70 \mathrm{~d}(4.4)$ & $0.78 \mathrm{~d}(4.8)$ & $0.76 \mathrm{~d}(4.8)$ & $0.68 \mathrm{~d}(4.4)$ \\
\hline 20 & $2.03 \mathrm{~m}$ & $2.10 \mathrm{~m}$ & $2.05 \mathrm{~m}$ & $2.02 \mathrm{~m}$ \\
\hline 21 & $0.86 \mathrm{~d}(6.4)$ & $0.89 \mathrm{~d}(6.8)$ & $0.87 \mathrm{~d}(6.4)$ & $0.86 \mathrm{~d}(6.0)$ \\
\hline \multirow[t]{2}{*}{22} & $1.35 \mathrm{~m}$ & $1.40 \mathrm{~m}$ & $1.38 \mathrm{dd}(2.4,14.0)$ & $2.18 \mathrm{~m}$ \\
\hline & $1.86 \mathrm{~m}$ & $1.90 \mathrm{dd}(4.0,14.0)$ & $1.87 \mathrm{dd}(4.0,14.0)$ & $2.51 \mathrm{~m}$ \\
\hline \multicolumn{5}{|l|}{23} \\
\hline \multirow[t]{2}{*}{24} & $1.66 \mathrm{~m}$ & $1.70 \mathrm{~m}$ & $1.69 \mathrm{~d}(1.2)$ & $2.47 \mathrm{dd}(4.8,17.2)$ \\
\hline & $2.38 \mathrm{dd}(8.4,12.8)$ & 2.40 overlap & 2.38 overlap & $2.93 \mathrm{dd}(12.4,17.2)$ \\
\hline 25 & $2.87 \mathrm{~m}$ & $2.93 \mathrm{~m}$ & $2.91 \mathrm{~m}$ & $2.96 \mathrm{~m}$ \\
\hline \multicolumn{5}{|l|}{26} \\
\hline 27 & 1.19 overlap & $1.25 \mathrm{~d}(7.2)$ & $1.22 \mathrm{~d}(7.2)$ & $1.22 \mathrm{~d}(9.6)$ \\
\hline 28 & $1.17 \mathrm{~s}$ & $1.12 \mathrm{~s}$ & $1.09 \mathrm{~s}$ & $0.92 \mathrm{~s}$ \\
\hline \multirow[t]{2}{*}{29} & $1.18 \mathrm{~s}$ & $4.73 \mathrm{dd}(1.6,2.0)$ & $4.71 \mathrm{dd}(2.0,1.6)$ & $1.25 \mathrm{~s}$ \\
\hline & & $4.80 \mathrm{~d}(2.0)$ & $4.77 \mathrm{~d}(2.0)$ & \\
\hline 30 & $1.08 \mathrm{~s}$ & $1.67 \mathrm{~s}$ & $1.65 \mathrm{~s}$ & $1.21 \mathrm{~s}$ \\
\hline $1^{\prime}$ & $4.05 \mathrm{q}(6.8)$ & $4.03 \mathrm{t}(6.8)$ & $3.61 \mathrm{~s}$ & $4.11 \mathrm{q}(6.8)$ \\
\hline $2^{\prime}$ & 1.19 overlap & 1.59 overlap & & $1.25 \mathrm{t}(6.8)$ \\
\hline $3^{\prime}$ & & 1.37 overlap & & \\
\hline $4^{\prime}$ & & $0.93 \mathrm{t}(7.6)$ & & \\
\hline
\end{tabular}


Table $2{ }^{13} \mathrm{C}$ (100 MHz) NMR spectroscopic data of compounds 1-4 in $\mathrm{CDCl}_{3}$

\begin{tabular}{|c|c|c|c|c|}
\hline \multirow[t]{2}{*}{ No. } & \multicolumn{4}{|c|}{$\delta_{\mathrm{C}}(\delta$ in $\mathrm{ppm})$} \\
\hline & 1 & 2 & 3 & 4 \\
\hline 1 & $32.2(\mathrm{t})$ & $28.6(t)$ & $28.6(t)$ & $32.3(\mathrm{t})$ \\
\hline 2 & $29.5(\mathrm{t})$ & $31.6(\mathrm{t})$ & $31.4(\mathrm{t})$ & $26.4(t)$ \\
\hline 3 & $174.6(\mathrm{~s})$ & $174.0(\mathrm{~s})$ & $174.3(\mathrm{~s})$ & $174.8(\mathrm{~s})$ \\
\hline 4 & $76.1(\mathrm{~s})$ & $149.2(\mathrm{~s})$ & $149.2(\mathrm{~s})$ & $76.3(\mathrm{~s})$ \\
\hline 5 & $48.1(\mathrm{~d})$ & $46.1(\mathrm{~d})$ & $46.1(\mathrm{~d})$ & 45.2 (d) \\
\hline 6 & $25.0(\mathrm{t})$ & $27.5(\mathrm{t})$ & $27.5(\mathrm{t})$ & $25.4(t)$ \\
\hline 7 & $26.0(\mathrm{t})$ & $25.5(\mathrm{t})$ & $25.5(\mathrm{t})$ & $25.7(\mathrm{t})$ \\
\hline 8 & 45.4 (d) & $47.9(\mathrm{~d})$ & $47.8(\mathrm{~d})$ & 48.6 (d) \\
\hline 9 & $21.8(\mathrm{~s})$ & 20.8 (s) & $20.8(\mathrm{~s})$ & $22.6(\mathrm{~s})$ \\
\hline 10 & $27.6(\mathrm{~s})$ & $27.7(\mathrm{~s})$ & $27.6(\mathrm{~s})$ & $26.5(\mathrm{~s})$ \\
\hline 11 & $26.7(t)$ & $26.9(\mathrm{t})$ & $26.9(\mathrm{t})$ & $28.3(\mathrm{t})$ \\
\hline 12 & $31.1(\mathrm{t})$ & $31.0(\mathrm{t})$ & $31.0(\mathrm{t})$ & $33.0(\mathrm{t})$ \\
\hline 13 & $43.5(\mathrm{~s})$ & $43.8(\mathrm{~s})$ & $43.8(\mathrm{~s})$ & $44.9(\mathrm{~s})$ \\
\hline 14 & $47.3(\mathrm{~s})$ & $47.4(\mathrm{~s})$ & $47.4(\mathrm{~s})$ & $49.0(\mathrm{~s})$ \\
\hline 15 & $41.1(\mathrm{t})$ & $40.8(\mathrm{t})$ & $40.8(\mathrm{t})$ & $35.9(\mathrm{t})$ \\
\hline 16 & 77.4 (d) & $77.3(\mathrm{~d})$ & $77.2(\mathrm{~d})$ & $30.2(t)$ \\
\hline 17 & $54.8(\mathrm{~d})$ & $54.8(\mathrm{~d})$ & $54.8(\mathrm{~d})$ & $52.3(\mathrm{~d})$ \\
\hline 18 & $19.4(\mathrm{q})$ & $19.3(\mathrm{q})$ & $19.3(\mathrm{q})$ & $18.5(\mathrm{q})$ \\
\hline 19 & $32.4(\mathrm{t})$ & $31.6(\mathrm{t})$ & $31.6(\mathrm{t})$ & $30.9(\mathrm{t})$ \\
\hline 20 & 29.9 (d) & $30.0(\mathrm{~d})$ & $30.0(\mathrm{~d})$ & $33.0(\mathrm{~d})$ \\
\hline 21 & $19.1(\mathrm{q})$ & $19.2(\mathrm{q})$ & $19.2(\mathrm{q})$ & $19.2(q)$ \\
\hline 22 & $44.1(\mathrm{t})$ & $44.2(\mathrm{t})$ & $44.1(\mathrm{t})$ & $50.2(\mathrm{t})$ \\
\hline 23 & $107.3(\mathrm{~s})$ & $107.3(\mathrm{~s})$ & $107.3(\mathrm{~s})$ & $209.3(\mathrm{~s})$ \\
\hline 24 & $42.6(\mathrm{t})$ & $42.7(\mathrm{t})$ & $42.7(\mathrm{t})$ & $46.4(\mathrm{t})$ \\
\hline 25 & $34.1(\mathrm{~d})$ & $34.2(\mathrm{~d})$ & 34.1 (d) & 34.4 (d) \\
\hline 26 & $179.7(\mathrm{~s})$ & 179.8 (s) & $179.7(\mathrm{~s})$ & $180.8(\mathrm{~s})$ \\
\hline 27 & $14.9(\mathrm{q})$ & $14.9(\mathrm{q})$ & $14.9(\mathrm{q})$ & $16.9(q)$ \\
\hline 28 & $31.7(q)$ & $23.1(\mathrm{q})$ & $23.0(\mathrm{q})$ & $19.5(\mathrm{q})$ \\
\hline 29 & $25.8(\mathrm{q})$ & $111.6(\mathrm{t})$ & $111.6(\mathrm{t})$ & $31.6(q)$ \\
\hline 30 & $23.1(\mathrm{q})$ & 19.7 (q) & $19.7(q)$ & $26.2(q)$ \\
\hline $1^{\prime}$ & $60.2(\mathrm{t})$ & $64.2(\mathrm{t})$ & $51.5(\mathrm{q})$ & $60.3(\mathrm{t})$ \\
\hline $2^{\prime}$ & $14.1(\mathrm{q})$ & $30.6(t)$ & & $14.2(\mathrm{q})$ \\
\hline $3^{\prime}$ & & $19.1(\mathrm{t})$ & & \\
\hline $4^{\prime}$ & & $13.7(q)$ & & \\
\hline
\end{tabular}

the $\mathrm{C}-20$ position of $\mathbf{1}$ should be $R$-configuration, too. Zhao et al. reported a serial of similar 16,23-epoxy-26(23)-olide3,4-secocycloartan-3-oic acid esters, and determined their absolute configurations by single crystal $\mathrm{X}$-ray diffraction [13]. By comparing the Cotton effect (-0.7 at $223 \mathrm{~nm})$ of 1 in ECD spectrum with those known compounds [13], in combination with analysis of chemical shifts, the absolute configurations of C-23 and C-25 positions of $\mathbf{1}$ were proposed to be $S$ - and $R$-configuration, respectively. Thus, the structure of 1 was elucidated as $(20 R, 23 S, 25 R)$-4-hydroxy16,23-epoxy-26(23)-olide-3,4-secocycloartan-3-oic acid ethyl ester, and named pseudolactone A.

Compound 2 was obtained as colorless oil. Its molecular formula was determined as $\mathrm{C}_{34} \mathrm{H}_{54} \mathrm{O}_{6}$, by HR-ESI-MS spectrum. The ${ }^{1} \mathrm{H}$ and ${ }^{13} \mathrm{C}$ NMR spectroscopic data (Tables 1 and 2) of $\mathbf{2}$ showed typical signals similar to those of $\mathbf{1}$, including two ester carbonyls $\left(\delta_{\mathrm{C}} 174.0,179.8\right)$, a ketal carbon at $\delta_{\mathrm{C}}$ $107.3(\mathrm{C}-23)$, an oxygenated methine at $\delta_{\mathrm{C}} 77.3(\mathrm{C}-16)$, a cyclopropyl at $\delta_{\mathrm{H}} 0.42(\mathrm{~d}, J=4.8 \mathrm{~Hz}), 0.78(\mathrm{~d}, J=4.8 \mathrm{~Hz})$ and $\delta_{\mathrm{C}} 31.6(\mathrm{t})$, one oxygen-bearing proton at $\delta_{\mathrm{H}} 4.09(\mathrm{td}$, $J=5.6,11.2 \mathrm{~Hz})$ and $\delta_{\mathrm{C}} 77.3(\mathrm{~d})$, one oxygenated methylene at $\delta_{\mathrm{H}} 4.03(\mathrm{t}, J=6.8 \mathrm{~Hz})$ and $\delta_{\mathrm{C}} 64.2(\mathrm{t})$, three singlet methyls at $\delta_{\mathrm{H}} 1.04(\mathrm{~s}), 1.12(\mathrm{~s})$, and $1.67(\mathrm{~s})$, two doublet methyls at $\delta_{\mathrm{H}} 0.89(\mathrm{~d}, J=6.8 \mathrm{~Hz})$ and $1.25(\mathrm{~d}, J=7.2 \mathrm{~Hz})$, one triplet methyl at $\delta_{\mathrm{H}} 0.93(\mathrm{t}, J=7.6 \mathrm{~Hz})$. These information revealed that compound 2 possessed the similar 16,23-epoxy-26(23)olide-3,4-secocycloartane skeleton to that of $\mathbf{1}$. The main differences between compounds $\mathbf{2}$ and $\mathbf{1}$ are that the resonance signals for one terminal double bond $\left(\delta_{\mathrm{H}} 4.73(\mathrm{dd}\right.$, $J=1.6,2.0 \mathrm{~Hz}), 4.80(\mathrm{~d}, J=2.0 \mathrm{~Hz}) ; \delta_{\mathrm{C}} 149.2(\mathrm{~s}), 111.6$ $(\mathrm{t}))$, and for one butoxy $\left(\delta_{\mathrm{H}} 4.03,1.59,1.37,0.93 ; \delta_{\mathrm{C}} 64.2\right.$ $(\mathrm{t}), 30.6(\mathrm{t}), 19.1(\mathrm{t}), 13.7(\mathrm{q}))$ in 2 , took place of the signals for the oxygenated quaternary carbon at $\delta_{\mathrm{C}} 76.1(\mathrm{~s}, \mathrm{C}-4)$ and the methyl at $\delta_{\mathrm{H}} 1.17(\mathrm{~s})$ and $\delta_{\mathrm{C}} 25.8(\mathrm{q})$, as well as for the ethoxy at $\delta_{\mathrm{H}} 4.05,1.19$ and $\delta_{\mathrm{C}} 60.2(\mathrm{t}), 14.1(\mathrm{q})$.

In ${ }^{1} \mathrm{H}-{ }^{1} \mathrm{H}$ COSY spectrum (Fig. 3), a butoxy was determined on the basis of the correlations of $\mathrm{H}_{2}-1^{\prime} / \mathrm{H}_{2}-2^{\prime} / \mathrm{H}_{2}-3^{\prime} /$ $\mathrm{H}_{3}-4^{\prime}$. The butoxy was linked to C-3 through key HMBC cross peak (Fig. 3) from $\mathrm{H}_{2}-1^{\prime}\left(\delta_{\mathrm{H}} 4.03\right)$ to the ester carbonyl at $\delta_{\mathrm{C}} 174.0$. The terminal double bond was evidenced to be
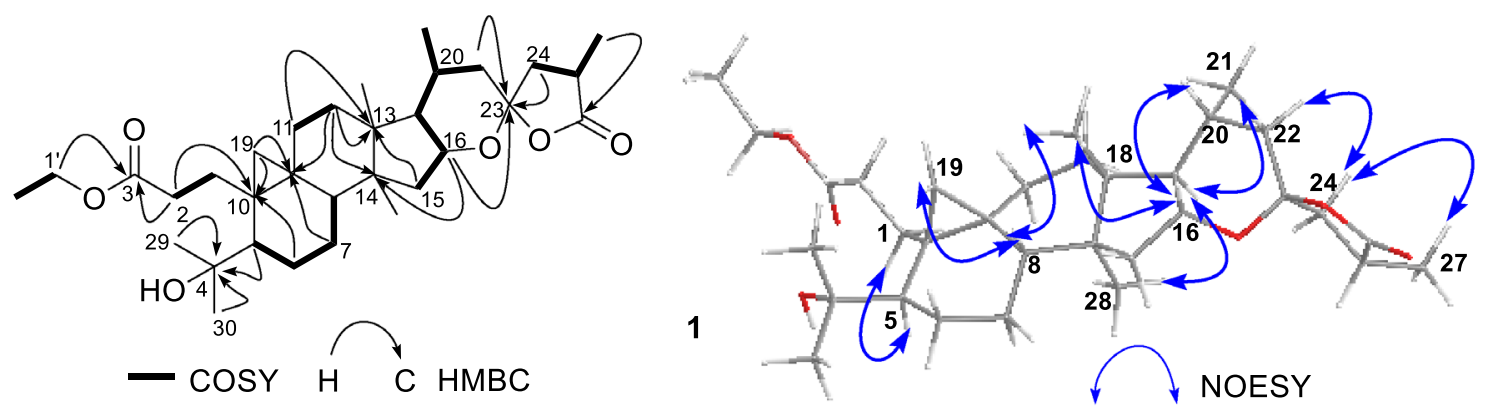

Fig. 2 Key ${ }^{1} \mathrm{H}^{-1} \mathrm{H}$ COSY, HMBC, and NOESY correlations of compound $\mathbf{1}$ 

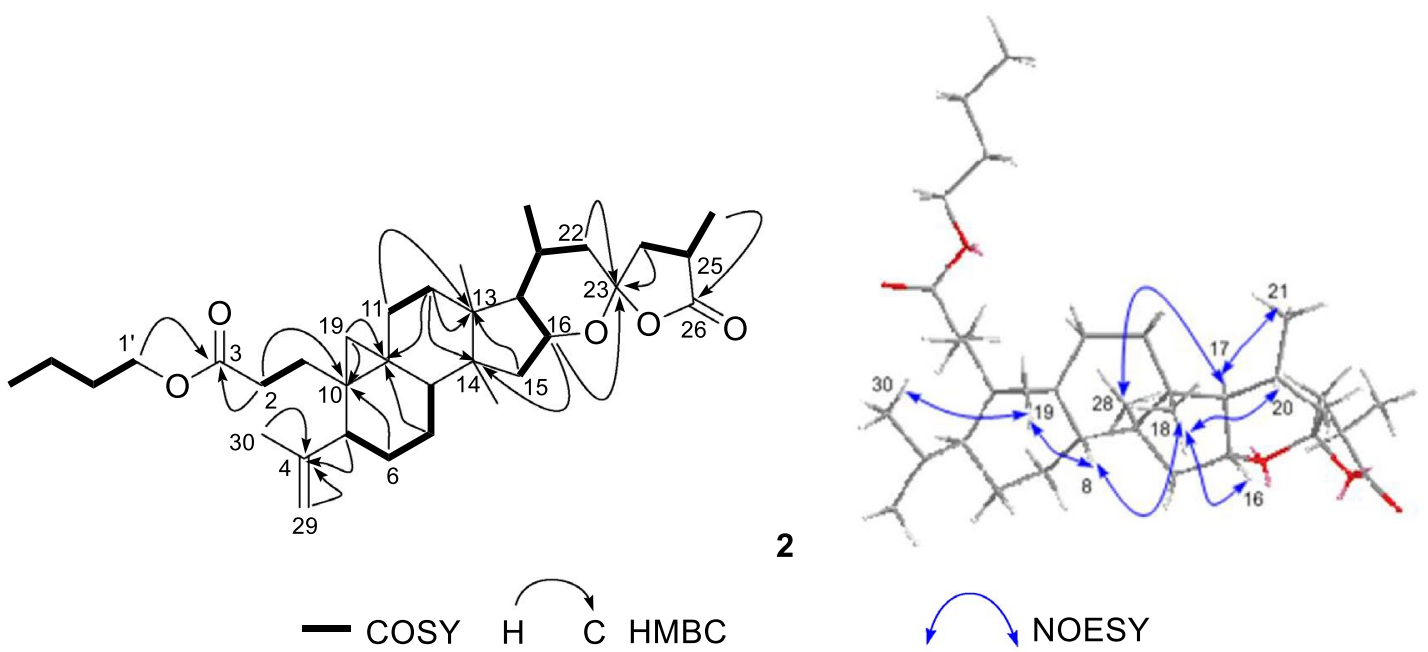

Fig. 3 Key ${ }^{1} \mathrm{H}-{ }^{1} \mathrm{H}$ COSY, HMBC, and NOESY correlations of compound 2

placed between C-4 and C-29 as shown by key HMBC correlations (Fig. 3) from $\mathrm{H}-5\left(\delta_{\mathrm{H}} 2.41\right), \mathrm{H}_{2}-29\left(\delta_{\mathrm{H}} 4.73\right.$ and 4.80$)$, $\mathrm{CH}_{3}-30\left(\delta_{\mathrm{H}} 1.67\right)$ to $\mathrm{C}-4\left(\delta_{\mathrm{C}} 149.2\right)$. In REOSY spectrum of 2, the observation of key NOE correlations (Fig. 3) of H-19 with $\mathrm{CH}_{3}-30, \mathrm{H}-8\left(\delta_{\mathrm{H}} 1.53\right)$, of $\mathrm{CH}_{3}-18\left(\delta_{\mathrm{H}} 1.04\right)$ with $\mathrm{H}-8$, $\mathrm{H}-16\left(\delta_{\mathrm{H}} 4.09\right)$ and $\mathrm{H}-20\left(\delta_{\mathrm{H}} 2.10\right)$, of H-17 $\left(\delta_{\mathrm{H}} 1.47\right)$ with $\mathrm{CH}_{3}-28(1.12)$ and $\mathrm{CH}_{3}-21\left(\delta_{\mathrm{H}} 0.89\right)$, suggested that the relative configuration of $\mathbf{2}$ was identical to that of compound $\mathbf{1}$. From structure, compound $\mathbf{2}$ could be considered as a dehydrated analogue of 1, implying that two compounds may share same configuration. Also, compound $\mathbf{2}$ had a negative Cotton effect ( -1.5$)$ at $201 \mathrm{~nm}$. Consequently, the structure of 2 was identified as $(20 R, 23 S, 25 R)$ - 16,23-epoxy-26(23)olide-3,4-secocycloartan-4(29)-en-3-oic acid $n$-butyl ester, and named pseudolactone $\mathrm{B}$.

The molecular formula of compound $\mathbf{3}$ was assigned as $\mathrm{C}_{31} \mathrm{H}_{46} \mathrm{O}_{5}$ with nine degrees of unsaturation, based on the hydrogen adduct ion $[\mathrm{M}+\mathrm{H}]^{+}$at $\mathrm{m} / z 499.3414$ (calcd. 499.3418 for $\mathrm{C}_{31} \mathrm{H}_{47} \mathrm{O}_{5}{ }^{+}$). Its molecular weight is $42 \mathrm{Da}$ less than that of 2. The ${ }^{1} \mathrm{H}$ and ${ }^{13} \mathrm{C}$ NMR spectra (Tables 1 and 2 ) were quite close to those of $\mathbf{2}$. The only difference was that a methoxyl at $\delta_{\mathrm{H}} 3.61$ and $\delta_{\mathrm{C}} 51.5$ was observed in $\mathbf{3}$, instead of those signals for the butoxy $\left(\delta_{\mathrm{H}} 4.03,1.59,1.39\right.$, 0.93; $\left.\delta_{\mathrm{C}} 64.2(\mathrm{t}), 30.6(\mathrm{t}), 19.1(\mathrm{t}), 13.7(\mathrm{q})\right)$ in 2. Key HMBC correlation from the methoxyl proton at $\delta_{\mathrm{H}} 3.61$ to the ester carbonyl at $\delta_{\mathrm{C}} 174.3$ further confirmed the above deduction, and established the structure of $\mathbf{3}$ as $(20 R, 23 S, 5 R)-16,23-$ epoxy-26(23)-olide-3,4-secocycloartan-4(29)-en-3-oic acid methyl ester, and given the name pseudolactone $\mathrm{C}$.

Compound 4 had a molecular formula $\mathrm{C}_{32} \mathrm{H}_{52} \mathrm{O}_{6}$ with seven degrees of unsaturation, as evidenced by positive HRESI-MS at $m / z 555.3674[\mathrm{M}+\mathrm{Na}]^{+}$. The ${ }^{1} \mathrm{HNMR}$ spectroscopic data (Table 1) of $\mathbf{4}$ exhibited four singlet methyls at $\delta_{\mathrm{H}} 1.00(\mathrm{~s}), 0.92(\mathrm{~s}), 1.25(\mathrm{~s})$, and $1.21(\mathrm{~s})$, two doublet methyls at $\delta_{\mathrm{H}} 0.86(\mathrm{~d}, J=6.0 \mathrm{~Hz})$ and $1.22(\mathrm{~d}, J=9.6 \mathrm{~Hz})$, one triplet methyl at $\delta_{\mathrm{H}} 1.25(\mathrm{t}, J=6.8 \mathrm{~Hz})$, and an oxygenated methylene at $\delta_{\mathrm{H}} 4.11(2 \mathrm{H}, \mathrm{q}, J=6.8 \mathrm{~Hz})$. In addition, a typical $\mathrm{AB}$ coupling system was observed at $\delta_{\mathrm{H}} 0.57(1 \mathrm{H}$, $\mathrm{d}, J=4.4 \mathrm{~Hz})$ and $0.68(1 \mathrm{H}, \mathrm{d}, J=4.4 \mathrm{~Hz}) . \mathrm{In}{ }^{13} \mathrm{C} \mathrm{NMR}$ spectrum (Table 2), thirty-two carbon resonances were observed, including 7 methyls $\left(\delta_{\mathrm{C}} 18.5,19.2,16.9,19.5\right.$, $31.6,26.2,14.2), 12$ methylenes (including one oxygenated methylene at $\left.\delta_{\mathrm{C}} 60.3\right), 5$ methines, and 8 quaternary carbons (including one ester carbonyl at $\delta_{\mathrm{C}} 174.8$, one carboxyl at $\delta_{\mathrm{C}}$ 180.8 , one ketone carbonyl at $\delta_{\mathrm{C}} 209.3$, and one oxygenated quaternary carbon at $\delta_{\mathrm{C}} 76.3$ ). Deducting three degrees of unsaturation accounted for one ketone carbonyl and two carboxylic carbon, the remaining four degrees of unsaturation were indicative of the tetracyclic ring system of 4 . The NMR spectroscopic data (Tables 1 and 2) of $\mathbf{4}$ quite resemble those of known compound pseudolarnoid G ((25S)-4-hydroxy3,4-seco-cycloartan-23-one-3,26-dioic acid methyl), previously reported from the seeds of the tilted plant [13]. The main differences are that compound $\mathbf{4}$ had an ethoxy ester and one carboxyl functionalities, while pseudolarnoid $\mathrm{G}$ had two methyl ester functionalities.

The diagnostic chemical shifts at $\delta_{\mathrm{C}} 174.8$ (ester carbonyl) and $\delta_{\mathrm{C}} 76.3$ (s) were indicative of oxidative cleavage of ring A between C-3 and C-4, and formed an ethyl ester at $\mathrm{C}-3$ and an oxygenated isopropyl moiety at $\mathrm{C}-4$. The deduction was evidenced by key ${ }^{1} \mathrm{H}-{ }^{1} \mathrm{H}$ COSY correlation (Fig. 4) between $\mathrm{H}_{2}-1^{\prime}\left(\delta_{\mathrm{H}} 4.11\right)$ and $\mathrm{H}_{2}-2^{\prime}\left(\delta_{\mathrm{H}} 1.25\right)$, and between $\mathrm{H}_{2}-1$ and $\mathrm{H}_{2}-2$, together with $\mathrm{HMBC}$ correlations (Fig. 4) of $\mathrm{H}_{2}-1$ and $\mathrm{H}_{2}-1^{\prime}$ with $\mathrm{C}-3\left(\delta_{\mathrm{C}} 174.8\right)$, of $\mathrm{CH}_{3}-29\left(\delta_{\mathrm{H}} 1.25\right)$, $\mathrm{CH}_{3}-30\left(\delta_{\mathrm{H}} 1.21\right), \mathrm{H}-5\left(\delta_{\mathrm{H}} 1.85\right), \mathrm{H}_{2}-6\left(\delta_{\mathrm{H}} 0.69,1.73\right)$ with the oxygenated quaternary carbon at $\delta_{\mathrm{C}} 76.3(\mathrm{C}-4)$. Also, 

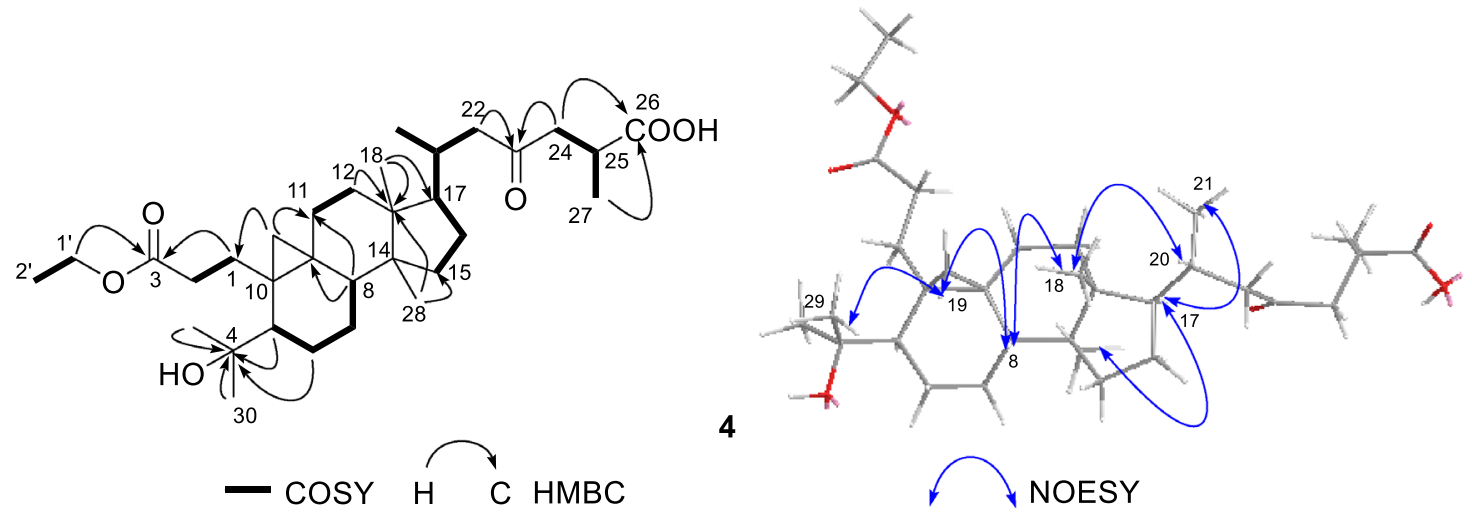

Fig. 4 Key ${ }^{1} \mathrm{H}-{ }^{1} \mathrm{H}$ COSY, HMBC, and NOESY correlations of compound 4

the ketone carbonyl at $\delta_{\mathrm{C}} 209.3$ was assigned to be C-23 on the basis of $\mathrm{HMBC}$ correlations from $\mathrm{H}_{2}-22$ and $\mathrm{H}_{2}-24$ to the ketone carbonyl. Key HMBC cross-peaks of $\mathrm{H}_{2}-24$ and $\mathrm{CH}_{3}-27\left(\delta_{\mathrm{H}} 1.22(\mathrm{~d}, J=9.6 \mathrm{~Hz})\right.$ supported the attribution of C-26 carboxyl. In the ROESY spectrum, key NOE correlations (Fig. 4) of $\mathrm{H}-20$ with $\mathrm{CH}_{3}-18$, of $\mathrm{H}-8\left(\delta_{\mathrm{H}} 1.30\right)$ with $\mathrm{CH}_{3}-18$ and $\mathrm{H}-19$, and of $\mathrm{CH}_{3}-29$ with $\mathrm{H}-19$ indicated that $\mathrm{H}-8, \mathrm{CH}_{3}-18, \mathrm{CH}_{2}-19, \mathrm{H}-20$, and 4-hydroxyl isopropyl are $\beta$-oriented, whereas $\mathrm{H}-17$ and $\mathrm{CH}_{3}-28$ were $\alpha$-oriented based on the NOE cross-peak of $\mathrm{H}-17$ with $\mathrm{CH}_{3}-28$. With regard to the absolute configurations of two chiral centers (C-20 and C-25) at C-17 side chain, Zhao et al. had ever determined the absolute configurations of C-20 and C-25 of similar compound pseudolarnoid $\mathrm{G}$ as $R$ and $S$, respectively, by single crystal X-ray diffraction. The ECD spectrum of compound 4 showed a negative Cotton effect -1.5 at $285 \mathrm{~nm}$, in accordance with that of pseudolarnoid $\mathrm{G}(-1.23(283 \mathrm{~nm})$ ), revealed that compound $\mathbf{4}$ had same absolute configuration as that of pseudolarnoid G. Therefore, the structure of $\mathbf{4}$ was identified as $(20 R, 25 S)$-4-hydroxy-23-oxo-3,4-secocycloartan-26-oic acid-3-ethyl ester, and named pseudolactone D.

\section{Experimental Section}

\subsection{General Experimental Procedures}

Optical rotations were measured with a Perkin-Elmer 341 polarimeter. IR spectra were recorded with a Bruker Vector-22 Spectrophotometer with $\mathrm{KBr}$ discs. NMR spectra were recorded with Bruker $D R X-400$ spectrometer $(400 \mathrm{MHz})$. The chemical shifts $(\delta)$ are given in ppm with TMS as internal standard and coupling constants $(J)$ are given in Hz. MS spectra were recorded with a Agilent MSDTrap-XCT (for ESI) and Waters Micro-mass Q-TOF mass spectrometer (for HR-ESI-MS), in $m / z$. Column chromatographic separations were carried out by using silica gel
(200-300 mesh; Marine Chemical Factory, Qingdao, P. R. China), Sephadex LH-20 (Pharmacia Fine Chemicals, Piscataway, NJ, USA) as packing material. TLC was carried out on precoated silica gel GF 254 plates (Yantai Chemical Industrials) and the TLC spots were viewed at $254 \mathrm{~nm}$ and visualized by using $10 \%$ sulfuric acid in alcohol containing $10 \mathrm{mg} / \mathrm{mL}$ vanillin.

\subsection{Plant Material}

The cones of $P$. amabilis were collected in Jiu Jiang, Jiangxi province, P. R. China, in October 2010, and authenticated by Prof. Han-Ming Zhang of Second Military Medical University. A voucher specimen (No. 20101015) is deposited in School of Pharmacy, Second Military Medical University.

\subsection{Extraction and Isolation}

The air-dried cones $(12.0 \mathrm{~kg})$ of $P$. amabilis were ground into powder and extracted with $80 \% \mathrm{EtOH}$ for four times at room temperature to give a crude extract, which was further partitioned with petroleum ether $\left(60-90{ }^{\circ} \mathrm{C}\right)(\mathrm{PE}), \mathrm{CHCl}_{3}$, and EtOAc, successively. The $\mathrm{CHCl}_{3}$-soluable extract was subjected to a silica gel column chromatography (CC) eluting with a gradient PE/EtOAc (from 30:0 to 0:1) to obtain eight fractions $1-8$. Fraction 2 (58 g) was chromatographed over RP-18 column eluting with $\mathrm{MeOH} / \mathrm{H}_{2} \mathrm{O}$ (from 3:7 to 10:0) to afford five subfractions. Subfraction 2 was further chromatographed on a silica gel column $\left(\mathrm{CH}_{2} \mathrm{Cl}_{2} / \mathrm{PE}\right.$, from 0:20 to 1:0, and $\mathrm{MeOH}$ ) and purified by preparative TLC (cyclohexane $\left./ \mathrm{CH}_{2} \mathrm{Cl}_{2} / \mathrm{EtOAc}, 20: 1: 1\right)$ to afford 2 (20 mg) and $\mathbf{3}(20 \mathrm{mg})$. Subfraction 4 was separated by repeated column chromatography on Sephadex LH-20 $\left(\mathrm{CHCl}_{3} / \mathrm{MeOH}\right.$, $1: 1$, and $\mathrm{MeOH}$ ), and then purified by preparative TLC (cyclohexane $\left./ \mathrm{CH}_{2} \mathrm{Cl}_{2} / \mathrm{EtOAc}, 15: 1: 1\right)$ to yield $\mathbf{1}(10 \mathrm{mg}$ ). Fraction 7 ( $70 \mathrm{~g})$ was separated by $\mathrm{RP}-18 \mathrm{CC}\left(\mathrm{MeCN} / \mathrm{H}_{2} \mathrm{O}\right.$, from $2: 8$ to 10:0) to afford 6 subfractions. Subfraction 3 
was further chromatographed on a silica gel column $\left(\mathrm{CHCl}_{3} /\right.$ $\mathrm{MeOH}$ from 50:1 to 0:1) and purified by preparative TLC (PE/EtOAc/MeOH, 20:1:0.1) to afford 4 (8 mg).

\subsubsection{Pseudolactone A (1)}

Colorless oil, $[\alpha] 45.1 \quad\left(c=0.37, \mathrm{CH}_{2} \mathrm{Cl}_{2}\right)$. CD $\left(c=2.83 \mathrm{mmol} / \mathrm{L}, \mathrm{CH}_{3} \mathrm{CN}, 20^{\circ} \mathrm{C}\right) \mathrm{nm}(\Delta \varepsilon) 223(-0.7)$. IR (KBr) $\nu_{\max } 1731,1778,2964 \mathrm{~cm}^{-1}$. For ${ }^{1} \mathrm{H}$ and ${ }^{13} \mathrm{C}$ NMR data $\left(400 \mathrm{MHz}, \mathrm{CDCl}_{3}\right.$ ), see Tables 1 and 2. ESI-MS: $\mathrm{m} / \mathrm{z} 553.5[\mathrm{M}+\mathrm{Na}]^{+}, 529.3[\mathrm{M}-\mathrm{H}]^{-}$. HR-ESI-MS: $\mathrm{m} / \mathrm{z}$ $531.3678[\mathrm{M}+\mathrm{H}]^{+}\left(\right.$calcd $\left._{32} \mathrm{H}_{51} \mathrm{O}_{6}^{+}, 531.3680\right)$.

\subsubsection{Pseudolactone B (2)}

Colorless oil, $[\alpha] 51.6\left(c=0.24, \mathrm{CH}_{2} \mathrm{Cl}_{2}\right)$. CD $\left(c=2.11 \mathrm{mmol} / \mathrm{L}, \mathrm{CH}_{3} \mathrm{CN}, 20{ }^{\circ} \mathrm{C}\right) \mathrm{nm}(\Delta \varepsilon) 201(-1.5)$. IR (KBr) $\nu_{\max } 1727,1770,2974 \mathrm{~cm}^{-1}$. For ${ }^{1} \mathrm{H}(400 \mathrm{MHz}$, $\left.\mathrm{CDCl}_{3}\right)$ and ${ }^{13} \mathrm{C}$ NMR data $\left(100 \mathrm{MHz}, \mathrm{CDCl}_{3}\right)$, see Tables 1 and 2. ESI-MS: $m / z 563.2[\mathrm{M}+\mathrm{Na}]^{+}, 539.1[\mathrm{M}-\mathrm{H}]^{-}$. HRESIMS: $m / z 541.3902[\mathrm{M}+\mathrm{H}]^{+}\left(\right.$calcd $\mathrm{C}_{34} \mathrm{H}_{53} \mathrm{O}_{5}{ }^{+}$, 541.3888).

\subsubsection{Pseudolactone C (3)}

Colorless oil, $[\alpha] 51.1 \quad\left(c=0.23, \mathrm{CH}_{2} \mathrm{Cl}_{2}\right)$. CD $\left(c=2.61 \mathrm{mmol} / \mathrm{L}, \mathrm{CH}_{3} \mathrm{CN}, 20^{\circ} \mathrm{C}\right) \mathrm{nm}(\Delta \varepsilon) 201(-1.6)$. IR (KBr) $\nu_{\max } 1737,1778,2964 \mathrm{~cm}^{-1}$. For ${ }^{1} \mathrm{H}(400 \mathrm{MHz}$, $\left.\mathrm{CDCl}_{3}\right)$ and ${ }^{13} \mathrm{C}$ NMR data $\left(100 \mathrm{MHz}, \mathrm{CDCl}_{3}\right)$, sees Tables 1 and 2. ESIMS: $m / z 521.2[\mathrm{M}+\mathrm{Na}]^{+}$. HR-ESI-MS: $\mathrm{m} / \mathrm{z}$ 499.3414 [M+H] $]^{+}\left(\right.$calcd $\left.\mathrm{C}_{31} \mathrm{H}_{47} \mathrm{O}_{5}^{+}, 499.3418\right)$.

\subsubsection{Pseudolactone D (4)}

White amorphous powder, $[\alpha] 51.6\left(c=0.23, \mathrm{CH}_{2} \mathrm{Cl}_{2}\right)$. $\mathrm{CD}$ $\left(c=1.88 \mathrm{mmol} / \mathrm{L}, \mathrm{CH}_{3} \mathrm{CN}, 20{ }^{\circ} \mathrm{C}\right) \mathrm{nm}(\Delta \varepsilon) 210(-1.9)$, 285 (- 1.5). IR (KBr) $\nu_{\max } 1712,1735,2873,2925,2962$, $3440 \mathrm{~cm}^{-1}$. For ${ }^{1} \mathrm{H}\left(400 \mathrm{MHz}, \mathrm{CDCl}_{3}\right)$ and ${ }^{13} \mathrm{C} \mathrm{NMR}$ data $\left(100 \mathrm{MHz}, \mathrm{CDCl}_{3}\right.$ ), see Tables 1 and 2. ESI-MS: $\mathrm{m} / z$ 531.4 $[\mathrm{M}-\mathrm{H}]^{-}$. HR-ESI-MS $\mathrm{m} / \mathrm{z} 555.3674[\mathrm{M}+\mathrm{Na}]^{+}$(calcd $\mathrm{C}_{32} \mathrm{H}_{52} \mathrm{O}_{6} \mathrm{Na}^{+}$, 555.3656).

Acknowledgements The work was supported by NSFC (31870327, 81230090, 81520108030, 1302658), National Major Project of China
(2018ZX09731016-005), The Key Research and Development Program of China (2017YFC1702002, 2017YFC1700200), Professor of Chang Jiang Scholars Program, Scientific Foundation of Shanghai China (17431902800, 16401901300), Shanghai Engineering Research Center for the Preparation of Bioactive Natural Products (10DZ2251300).

\section{Compliance with Ethical Standards}

Conflict of interest The authors declare that there are no conflicts of interest.

Open Access This article is licensed under a Creative Commons Attribution 4.0 International License, which permits use, sharing, adaptation, distribution and reproduction in any medium or format, as long as you give appropriate credit to the original author(s) and the source, provide a link to the Creative Commons licence, and indicate if changes were made. The images or other third party material in this article are included in the article's Creative Commons licence, unless indicated otherwise in a credit line to the material. If material is not included in the article's Creative Commons licence and your intended use is not permitted by statutory regulation or exceeds the permitted use, you will need to obtain permission directly from the copyright holder. To view a copy of this licence, visit http://creativecommons.org/licenses/by/4.0/.

\section{References}

1. Editor committee, Flora of China, vol. 7 (Science Press, Beijing, 1978), pp. 196-200

2. G.P. Ni, Zhongguo Zhongyao Zazhi 3, 156-158 (1957)

3. P. Chiu, L.T. Leung, B.C.B. Ko, Nat. Prod. Rep. 27, 1066-1083 (2010)

4. Z.L. Li, K. Chen, D.J. Pan, G.G. Xu, Acta. Chim. Sin. 47, 258$261(1989)$

5. S.P. Yang, Y. Wu, J.M. Yue, J. Nat. Prod. 65, 1041-1044 (2002)

6. Z.L. Li, D.J. Pan, C.Q. Hu, Q.L. Wu, S.S. Yang, G.Q. Xu, Acta. Chim. Sin. 40, 447-457 (1982)

7. Z.L. Li, K. Chen, D.J. Pan, G.Q. Xu, Acta. Chim. Sin. 43, 786788 (1985)

8. G.F. Chen, Z.L. Li, D.J. Pan, J. Nat. Prod. 56, 1114-1122 (1993)

9. G.F. Chen, Z.L. Li, C.M. Tang, X. He, K. Chen, D.J. Pan, C.Q. $\mathrm{Hu}$, D.R. McPhail, A.T. McPhail, K.H. Lee, Heterocycles 31, 1903-1906 (1990)

10. E. Li, A.M. Clark, C.D. Hufford, J. Nat. Prod. 58, 57-67 (1995)

11. B. Li, D.Y. Kong, Y.H. Shen, K.L. Fu, R.C. Yue, Z.Z. Han, H. Yuan, Q.X. Liu, L. Shan, H.L. Li, X.W. Yang, W.D. Zhang, Chem. Commun. 49, 1187-1189 (2013)

12. B. Li, D.Y. Kong, Y.H. Shen, H. Yuan, R.C. Yue, Y.R. He, L. Lu, L. Shan, H.L. Li, J. Ye, X.W. Yang, J. Su, R.H. Liu, W.D. Zhang, Org. Lett. 14, 5432-5435 (2012)

13. X.T. Zhao, M.H. Yu, S.Y. Shi, C. Lei, A.J. Hou, Phytochemistry 171, 112229 (2020)

\section{Affiliations}

\section{Si-Jia Xiao ${ }^{1} \cdot$ Bo Li $^{1,2} \cdot$ Zheng-Rui Huang $^{3} \cdot$ Wen-Lin Yuan ${ }^{1} \cdot \mathrm{Ji} \mathrm{Ye}^{1} \cdot$ Hui-Liang $\mathrm{Li}^{1} \cdot \mathrm{Xi}^{1}-\mathrm{Ke} \mathrm{Xu}^{1} \cdot$ Yun-Heng Shen ${ }^{1}$ (1) Wei-Dong Zhang ${ }^{1,2}$}

Yun-Heng Shen

shenyunheng@hotmail.com
Wei-Dong Zhang

wdzhangy@hotmail.com 
1 Department of Phytochemistry, School of Pharmacy, Naval Medical University (Second Military Medical University), Shanghai 200433, China

2 State Key Laboratory of New Drug and Pharmaceutical Process, Shanghai Institute of Pharmaceutical Industry,
China State Institute of Pharmaceutical Industry, Shanghai 201203, China

3 Department of Applied Chemistry, Xi'an University of Technology, Xi'an 710048, China 